YEARBOOK

of ANTITRUST

and REGULATORY

STUDIES

www.yars.wz.uw.edu.pl
Peer-reviewed scientific periodical, focusing on legal and economic issues of antitrust and regulation. Creative Commons Attribution-No Derivative Works 3.0 Poland License.

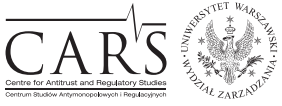

Centre for Antitrust and Regulatory Studies, University of Warsaw, Faculty of Management www.cars.wZ.uw.edu.pl

\title{
A Comparative Analysis of the Collective Dominance Definition in Ukrainian and European Law - the Electricity Market Case
}

\author{
by
}

Kseniia Smyrnova*

\section{CONTENTS}

\section{Introduction}

II. The concept of dominance: a comparative approach

III. Attempts at collective dominance definition in Ukrainian legislation with its comparison to EU practice

IV. Conclusions

\section{Abstract}

This paper follows a comparative approach to the analysis of collective dominance doctrine and practice in the EU and the enforcement practice in Ukraine. The aim of this paper is to assess the compliance of the Ukrainian competition authority's (AMCU) analysis of the national electricity market with EU law enforcement practice. The latter arises from Ukraine's wider duty to fulfil its international law obligation to comply with EU competition rules, based on Article 18 of the Treaty establishing the Energy Community also taking into account the interpretative criteria developed in EU case law (according to Article 94 of the Association Agreement between Ukraine and the EU). Article 255 of the Association Agreement, which clearly provides for the use of the principle of transparency, non-discrimination and neutrality when complying with the procedures of fairness, justice and the right of defence, also illustrates the necessity of carrying out research in this field.

* Doctor of Jur. Sciences (Dr. hab.), Associate Professor of the Chair of Comparative and European Law, Institute of International Relations, Kyiv National Taras Shevchenko University, Ukraine; ksenya.smyrnova@gmail.com. Article received: 30 May 2016; accepted: 26 September 2016.

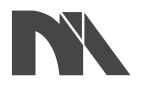

\section{Ministry of Science and Higher Education}

Republic of Poland
The creation of the English-language version of these publications is financed in the framework of contract No. 768/P-DUN/2016 by the Ministry of Science and Higher Education committed to activities aimed
at the promotion of education. 
The paper examines notions such as: the dominance doctrine, market power definition, economic strength and collective dominance in the EU enforcement practice. Special attention is placed on enforcement practice in the electricity market. Since the scrutinised market inquiry constitutes the first investigation into the Ukrainian electricity market, there is no national practice on this issue yet. For this reason, the analysis follows a wide comparative approach towards the principles of collective dominance in the electricity market in Ukraine.

The paper concludes that the AMCU's approach to the regulation of the electricity market in Ukraine confirms the necessity to reform the system of state regulation in the wholesale electricity market and in the market of services for electricity transmission. In order to develop competition in the electricity market, it is also necessary to change the system for tariff and pricing policy formation on the part of the National Energy and Utilities Regulatory Commission of Ukraine and the Ministry of Energy and Coal-Mining Industry of Ukraine. Stressed is also the necessity to follow the approach and criteria of EU competition law with regard to the determination of market dominance. This requirement is stipulated by Ukraine's international legal obligations arising from Articles 18 and 94 of the Treaty establishing the Energy Community and Article 255 of the Association Agreement between the EU and Ukraine.

\section{Résumé}

Le présent article utilise une approche comparative afin d'analyser la doctrine et la pratique de la dominance collective dans l'Union européenne, ainsi que la pratique d'application du droit de la concurrence en Ukraine. L'objectif de l'article est d'évaluer la conformité de l'analyse de l'autorité ukrainienne de la concurrence ("AMCU") concernant le marché national de l'électricité avec la pratique de l'Union européenne dans cette matière. La conformité mentionnée ci-dessus découle de l'obligation internationale de l'Ukraine d'assurer la cohérence avec les règles européen du droit de la concurrence, basée sur l'article 18 du Traité instituant la Communauté de l'énergie, en tenant compte également des critères interprétatifs développés dans la jurisprudence de l'Union européenne (l'article 94 d'Accord d'association entre l'Ukraine et l'Union européenne). Larticle 255 de l'Accord d'association, qui prévoit clairement l'obligation d'application du principe de transparence, de non-discrimination et de neutralité dans le respect des procédures d'équité, de justice et de défense, démontre également la nécessité de mener des recherches dans ce domaine. Le document examine des notions telles que: la doctrine de la domination, la définition du pouvoir de marché, la force économique et la domination collective dans la pratique européenne de l'application du droit de la concurrence. Une attention particulière est accordée à la pratique d'application dans le domaine de marché de l'électricité. Vu que c'est la première analyse détaillée du marché ukrainien d'électricité, il n'existe pas encore le pratique nationale concernant ce sujet. Pour cette raison l'article utilise une approche comparative aux principes de dominance collective sur le marché de l'électricité en Ukraine. 
L'article conclut que l'approche de l'AMCU à la réglementation du marché de l'électricité en Ukraine confirme la nécessité de réformer le système de réglementation étatique sur le marché de gros de l'électricité et sur le marché des services de transmission d'électricité. Afin de développer la concurrence sur le marché de l'électricité, il est également nécessaire de modifier le système de formation des prix et tarifs par la Commission nationale de réglementation de l'énergie et des services publics d'Ukraine et par le Ministère de l'Energie et de l'Industrie minière du charbon de l'Ukraine. Larticle souligne également qu'il est nécessaire de suivre l'approche et les critères du droit européen de la concurrence en ce qui concerne la détermination de la dominance. Cette obligation découle des articles 18 et 94 du traité instituant la Communauté de l'énergie et de l'article 255 de l'Accord d'association entre l'Union européenne et l'Ukraine.

Key words: competition; collective dominance; EU; Ukraine; Antimonopoly Committee of Ukraine; wholesale electricity market.

JEL: K21; K23

\section{Introduction}

Ratified in September 2014, the EU-Ukraine Association Agreement ${ }^{1}$ is meant to ensure an effective competitive environment within the established free-trade area (Articles 253-267), it reproduces rules of EU competition law and contains provisions strictly referring to those rules (Smyrnova, 2015). Ukraine is a member of the Energy Community ${ }^{2}$ and has to fulfil obligations concerning the implementation of acquis, particularly in the electricity sector. More specifically, Article 18 of the Treaty establishing the Energy Community provides for the adherence with competition rules in this market (detailed in Appendix III which, in fact, reproduces EU competition rules found in Articles 101, 102, 106 and 107 TFEU). At the same time, the Association Agreement determines the compliance between its provisions and the

1 The Law of Ukraine "On the Ratification of the Association Agreement between Ukraine, on the One Part, and the European Union, the European Atomic Energy Community and Their Member States, on the Other Part", Gazette of the Verkhovna Rada of Ukraine 2014, No. 40, p. 2021.

2 On 18 December 2009, the Government Council of the Energy Community has made the decision of Ukraine's full-fledged membership in this international organization. The protocol of Ukraine's entering the Energy Community was signed on 24 September 2010 and ratified by the Verkhovna Rada of Ukraine in December 2010. The protocol provides for the inclusion of Ukraine into the members of Energy Community (Article 1) and contains the schedule of acquis implementation by Ukraine in the energy industry (Article 2) until 1 January 2018. 
provisions of the Treaty establishing the Energy Community, giving priority to the rules of the latter in case of a conflict. Accordingly, the rules of the Association Agreement cannot contravene EU law which is used in compliance with the provisions of this Agreement.

The Antimonopoly Committee of Ukraine (hereinafter, AMCU) presented on 24 December 2015 a Report on the investigations conducted between August and December 2015 into this sector of the economy (wholesale electricity market). This was the first in-depth analysis of this market ${ }^{3}$, and the first publicly available assessment of an investigation of the electricity market in Ukraine since the country gained its independence. Unfortunately, there is neither other enforcement practice, nor any doctrine in this sphere in Ukraine yet. In this Report, the AMCU stated that a dominant position exists in Ukraine held by the State Enterprise Energorynok (hereinafter, SE Energorynok) acting as the sole purchaser. At the same time, the AMCU prematurely declared the presence of a collective dominant position of three electricity generating companies on the basis of the sum of their market shares.

Upon implementing the provisions of the Association Agreement regarding the cooperation of the parties in the energy industry, the parties (in this case Ukraine) assume the duty to give priority to the legal or other acts complying with the Treaty establishing the Energy Community and effective EU law in this field. The compliance assessment should take into account all the decisions approved under Article 91 of the Treaty establishing the Energy Community 4 .

It should thus be mentioned that Ukrainian authorities should implement in their work not only the legislative acts and law enforcement practice of EU institutions, but also the judicial practice of European courts ${ }^{5}$ (for more information, see Smyrnova, 2014), seeing as it is ultimately the jurisprudence of European courts where the unified law enforcement practice of the EU is reflected.

The main aim of this article is to analyze in a comparative manner the concepts of dominance and collective dominance in the EU and how they were represented in the enforcement practice of the AMCU. Due to the complete absence of any enforcement practice in this sphere in Ukraine, it seems essential to provide a comparative analysis here based on EU practice in the relevant electricity market and the collective dominance definition.

\footnotetext{
3 The text of AMCU's presentation of the Report (text available only in Ukrainian) can be accessed at: http://www.amc.gov.ua/amku/doccatalog/document?id=119661\&schema=main (26.09.2016).

4 Article 278 of the Association Agreement.

5 Reference to EU courts means that the EU judicial system comprises the CJEU which includes the CJ and the GC under the TFEU. Hereinafter, EU court means ECJ or GC or CFI in accordance with the pre-Lisbon treaties.
} 


\section{The concept of dominance: a comparative approach}

The concept of a dominant position itself is not defined in the Treaty on the Functioning of the European Union (hereinafter, TFEU). The definition given by the European Court of Justice (hereinafter, ECJ) in the United Brands case is repeatedly quoted in the majority of European Commission (hereinafter, EC or Commission) decisions and EU judgments concerning the implementation of Article 102 TFEU. The ECJ stated that it is "a position of economic strength enjoyed by an undertaking which enables it to prevent effective competition being maintained on the relevant market by giving it the power to behave to an appreciable extent independently of its competitors and ultimately of its consumers"6.

The definition of a dominant position according to EU law was given by the ECJ in the Continental Can case: an undertaking holds a dominant position when it has the power to behave independently, which lets such companies to act without regard of their competitors, customers and sellers; it is a situation when they, due to their market share or their market share together with ownership of technological knowledge, raw material resources or capital, have the power to set prices or control the production or distribution of a significant portion of the relevant product ${ }^{7}$.

Later the ECJ confirmed and extended this definition in the Hoffman-La Roche case: "An undertaking which has a very large market share and holds it for some time (...) is by virtue of that share in a position of strength which makes it an unavoidable trading partner and which, already because of this secures for it, at the very least during relatively long periods, that freedom of action which is the special feature of a dominant position"

The concept of dominance consists of three basic mutually related elements?: "(a) there must be a position of economic strength on a market which (b) enables the undertaking(s) in question to prevent effective competition being maintained on that market by (c) affording it the power to behave independently to an appreciable extent".

${ }^{6}$ ECJ judgment of 14.02.1978, Case 27/76 United Brands, ECLI:EU:C:1978:22, para. 65, and ECJ judgment of 13 February 1979, Case 85/76 Hoffmann-La Roche, ECLI:EU:C:1979:36, para. 38.

7 ECJ judgment of 21.02.1973, Case 6/72 Europeembellage Corp and Continental Can Company Inc v. Commission, ECLI:EU:C:1973:22.

8 ECJ judgment of 13.02.1979, Case 85/76 Hoffmann-La Roche, ECLI:EU:C:1979:36, para. 41.

9 DG Competition discussion paper of 2005 on the application of Article 82 of the Treaty to exclusionary abuses, http://ec.europa.eu/competition/antitrust/art82/discpaper2005.pdf (26.09.2016), paras 21-23. 
First, dominance exists in relation to a market; it cannot exist in the abstract. It also implies that an undertaking either on its own, or together with other undertakings, must hold a leading position on that market compared to its rivals either independently or jointly with other enterprises. The second and third elements concern the link between the position of economic strength held by the undertaking concerned and the competitive process - the way in which the undertaking and other players act and inter-act on the market.

Both practice and doctrine prove that the size of the market share is not decisive in the definition of dominance. This aspect differs significantly from the formalized legislative approach of Article 12 of the Law of Ukraine on the Protection of Economic Competition (hereafter, LPEC) ${ }^{10}$, where the analysis of the existence of market power is weakly defined and directed to the right of undertakings to prove that they are subjected to competition. The ability to act independently from one's competitors, customers and consumers is the key distinguishing feature of this concept. While defining market dominance, both the EC and EU courts pay special attention to how effectively the enterprise blocks competitors from entering the market, as well as what is its market share, its economic potential and its access to the capital market.

Accordingly, while studying the electricity market and the features of dominance, the AMCU should have studied and substantiated its findings on the market power of the scrutinised undertakings, their opportunities to act independently from their competitors, consumers, suppliers and customers, the opportunity of the potentially dominant companies to prevent effective competition and to establish and maintain prices above the competitive level.

Summarising the EU experience, it should be mentioned that the fact of dominance in the market is proven by detecting the relative share of the dominant undertaking by establishing the fact of its contractual relations with its potential competitors (rivals) - a special system of relations with customers and suppliers that does not comply with the principles of fair competition in the relevant market. While determining market dominance, several issues are taken into account: the financial potential of the monopolist, lack of competitors, and the existence of potential dependence of third parties on the monopolist. Among other factors considered when defining a dominant position are: the proportion of shares of the undertaking and its closest competitors, the technological advantage of the enterprise over its competitors, the existence of a highly developed sales system and the lack of potential

10 Article 12 para. 3 stipulates that: "Monopoly (dominant) position is considered to be the entity whose market share exceeds 35 percent of the goods if he proves experiencing considerable competition". 
competitors. However, while studying all of these factors, their relation to the above elements of the dominant position must be considered (market power, prevention of competition etc.). In other words, it is not sufficient to only highlight certain features or factors, it is necessary to also examine whether they actually result in market power of the undertaking.

Procedurally, the examination of the abuse of a dominant position is usually performed by the EC and can then be reviewed by EU courts. According to Article 102 TFEU, one more issue has to be considered: if an enterprise (undertaking) occupies a dominant position, how significant is its market share? Some parts of the market may only be controlled in terms of supplies of a certain type of products or services. This is why it is important to determine the product market. As established in the Continental Can case, the definition of the market is crucial for the assessment of a dominant position, as "the relevant market is of essential significance, for the possibilities of competition can only be judged in relation to those characteristics of the products in question by virtue of which those products are particularly apt to satisfy an inelastic need and are only to a limited extent interchangeable with other products"11. It is extremely significant that the ECJ annulled the Commission decision in this case because it lacked arguments and evidences regarding the definition of the relevant market. The ECJ also supports the approach whereby "(...) the separation of the market object allows for establishing the space within which certain competition conditions are functioning and a predictable dominant enterprise is operating" 12 .

Unlike in Ukrainian law ${ }^{13}$, there are no certain mathematical criteria for the definition of dominance in EU law. Many criteria on the basis of which the decision is made are considered in each specific case. However, the market share of the dominant undertaking has to be rather large, usually over $50 \%$ (Jones and Sufrin, 2014, p. 298-303; Ortiz Blanco, 2012, p. 47; Vickers, 2006, p. 11; Monti, 2006, p. 45-46).

At the same time, according to EU practice, the existence of a large enterprise in the market does not mean in itself that it occupies a dominant position at all. An enterprise gains a dominant position if it can act in the market of the specified product independently from its competitors. In other words, an enterprise occupies a dominant position if it has market power (for more detail, see: Rosen and Williams, 1999; Jones and Sufrin, 2014, p. 298-303; Ortiz Blanco, 2012, p. 47; Vickers, 2006, p. 11; Monti, 2006,

11 ECJ judgment of 21.02.1973, Case 6/72 Europeembellage Corp and Continental Can Company Inc v. Commission, ECLI:EU:C:1973:22, para. 32.

12 ECJ judgment of 26.11.1998, Case C-7/97 Oscar Bronner GmbH \& CoKG v. Mediaprint, ECLI:EU:C:1998:569.

13 Article 12 of the Law of Ukraine on the Protection of Economic Competition. 
p. 45-46). It is hard to measure this power quantitatively. The market share held by the enterprise serves as the first indicator when considering the market dominance issue. It is clear that if the enterprise has a relatively small market share than its position cannot be dominant. In this regard, the Commission considers roughly that a market share below $40 \%$ is unlikely to be an indicator of market dominance ${ }^{14}$.

Barriers to market entry are another important factor that facilitates defining the existence of market dominance. Unfortunately, the AMCU did not apply the existing experience of the Commission and EU courts ${ }^{15}$ regarding the definition and assessment of entry barriers and their influence on competition and market power. In particular, the authority failed to take into account the influence exercised on market competition by electricity imports. Moreover, the existence of economic barriers for market entry and their impact on market power was not justified economically. Several additional issues were not analysed in this context either: the actual existence of entry barriers, factors leading to their appearance, their influence on the level on market competition and the activity of market participants, as well as entry barriers leading to the appearance or absence of market power. All this proves that the conclusions reached by the AMCU were unjustified and careless, and that the analysis was not in compliance with European standards and rules in the field of competition protection.

While analysing the position of the single customer (SE Energorynok) active in the nationwide electricity market, a number of issues should have been considered. These include the legislative features of the pricing policy undertaken by the National Energy and Utilities Regulatory Commission of Ukraine (hereafter, the NEURC), which has the authority to set prices in the electricity market. Directly relevant are also statutory solutions applicable in this field with respect to the Ministry of Energy and Coal-Mining Industry of Ukraine and the restrictions deriving from the law of Ukraine regarding the freedom to act and independence in decision-making binding SE Energorynok ${ }^{16}$. This factor was not reflected in the conclusions presented by the AMCU. Under such legislative conditions, it would be more appropriate

14 DG Competition discussion paper of 2005 on the application of Article 82 of the Treaty to exclusionary abuses, supra note 9 .

15 ECJ judgment of 6.04.1995, Cases C-241/91 P and C-242/91 Radio Telefis Eireann (RTE) and Independent Television Publications LTD (ITP) v. Commission (Magill), ECLI:EU:C:1995:98; CFI judgment of 6.10.1994, Case T-83/91 Tetra Pak International v. Commission (Tetra Pak II), ECLI:EU:T:1994:246; ECJ judgment of 14.02.1978, Case 27/76 United Brands, ECLI:EU:C:1978:22.

16 Agreement between the Wholesale Electricity Market of Ukraine participants (AWEMP) of 15.11.1996, the Resolution of the Cabinet of Ministers of Ukraine on the Formation of SE Energorynok of 5.05.2000, No. 755, The Official Bulletin of Ukraine 2000, No. 19, p. 49. 
to say that the monopsony of SE Energorynok in the electricity market is of a limited nature, created by the existing market model and the statutory acts governing the relations in this market. As such, the AMCU should not have declared that SE Energorynok holds a monopoly based solely on the fact that it occupies a $100 \%$ share of the market. The authority should have studies the functions and role of SE Energorynok not only as that of a "unified customer", but also as an element of the institutional monopoly of the State, represented by the authorities defining the conditions of product trade in this market. Such approach would comply with the main principles of defining a dominant position in EU law whereby the market share is not decisive in and of itself, and other factors defining the position of the undertaking in the market should be studied also.

\section{Attempts at collective dominance definition in Ukrainian legislation with its comparison to EU practice}

The European Union started applying the provision on collective dominance while analysing mergers and later transferred this assessment to Article 102 TFEU cases in the review of Nestle/Perrier ${ }^{17}$ in 1992. At the same time, the collective dominance concept has been actively applied and used in view of current Article 102 TFEU (in Flat Glass case ${ }^{18}$ ).

TFEU pays special attention to the concept of collective dominance which, in turn, is specified in EU judicial practice dedicated to the application of Article 102 TFEU.

European case law elaborated the following three conditions which give grounds to find the existence of collective dominance:

1) each entity that is a member of the collectively dominant entity shall be able to obtain, at a low cost, information on the behaviour of other members of the collective dominance;

2) members of the collective dominance shall have influence on the undertaking which: in case of any agreement between them - restricts competition, and in case of coordinated actions - deviates from the general policy on the given market;

3 ) the expected reaction of competitors, both existing and potential, shall not have any noticeable effect on the expected results of coordinated

17 Commission Decision of 22.07.1992 relating to a proceeding under Council Regulation (EEC) No. 4064/89 (Case No. IV/M.190 - Nestlé/Perrier), OJ L 356, 05.12.1992, p. 1.

18 CFI judgment of 10.03.1992, joined cases T-68/89, T-77/89 and T-78/89 Società Italiana Vetro et al. v. Commission (Flat Glass), ECLI:EU:T:1992:38. 
actions (general policy of the members of a collective dominance on the target market).

Moreover, as further analysis of EU judicial practice shows, the necessary conditions of collective dominance also include links between members of such dominance, joint policy on price increases etc., which allows them to act as a "single" economic unit in relations with customers. Collective dominance shall not be considered in the context of a single undertaking doctrine (a group of enterprises connected through relations of control) since the members of collective dominance are separate legal entities. According to the doctrine on a single economic entity, the EC shall decide on the dominant position of the parent company and shall address its decision to this company.

Article 102 TFEU refers to the abuse of collective dominance condition by one or more undertakings. The Court of First Instance (hereinafter, CFI) explained this concept in Flat Glass ${ }^{19}$. At the origin of this case, the EC accused two legally independent Italian manufacturers of creating a price cartel and setting the relevant production volume contrary to Article 101(1) TFEU. The Commission accused them also of violating Article 102 TFEU without, however, giving any particular justification of this aspect of its decision. The EC decided that the scrutinised companies, acting as a single entity on the market and establishing structural links through a systematic exchange of products, actually created a dominant position therein (as well as concluded agreements violating Article 101 TFEU) that had constituted a violation by itself. The CFI did not agree with this logic stating that it was not enough to use the same facts several times to transfer from Article 101 to Article 102 TFEU. However, it is possible that two or more undertakings connected through certain economic market structures actually hold a collective dominant position in relation to their competitors. The Commission in this case assumes that technological leadership obtained due to cooperation agreements and licenses eventually makes the behaviour of these companies independent of competitors, customers and consumers.

Another case worth mentioning is French-West African Shipowners Committees $^{20}$. The fact that the undertakings (ship owners) voluntarily united to coordinate their joint policy is a special feature of this case. In the decision of the Commission, the way of holding the Maritime Conference, which is a cartel by nature, can be referred to as a collective dominant position. In this particular case, such conclusion was based on the structural ties between ship owners as well as on complete exclusion of competition between them due to conference procedures, which led to strict centralised cargo control.

19 Ibidem.

20 Decision of French-West African Shipowners Committees, Re: Association of Danish Shipowners \& Denmark v. Navale Delmas Afrique, OJ L 134, 1992, p. 1. 
Yet attention should also be paid here to the fact that ship owners united and coordinated their policy, including pricing, on the basis of commercial agreements rather than legislative provisions and statutory conditions.

Compagnie Maritime Belge ${ }^{21}$ remains the most interesting case in this context. Following its results, the ECJ established a two stage analysis in order to find collective dominance: first, establishing the existence of a collective entity and second, proving that the undertaking is dominant in the market.

According to the opinion of the ECJ in the above case, collective dominance can be held by two or more undertakings which are legally independent of each other, provided that from an economic point of view they present themselves or act together as a collective undertaking. It is necessary to establish economic links or factors that may contribute to such links. An economic assessment and, in particular, an evaluation of the relevant market structure is of significance here. Apparently, this judgment seems to extend the concept of collective dominance by taking into account potential opportunities (those that have not yet appeared quite clearly) - it is another example of the tendency to substitute formal legal criteria by an economic approach. This case has thus settled a necessary element of collective dominance, namely the legal and economic links between the members of collective dominance. It confirmed that these undertakings can act as a single "collective" undertaking, adopt a joint policy and perform joint market behaviour, particularly with respect to prices.

In case of collective dominance, the approach of the Commission on the definition of the inter-relationships in the group, which was applied in the case of France v. Commission ${ }^{22}$, was supported in subsequent cases. In Gencor ${ }^{23}$ in particular, the ECJ found that "the relationships of interdependence existing between the parties" create potential coordination between them in the sense of forming collective dominance. The ECJ based its Gencor judgment on the interpretation of the concept of collective dominance, which was set out in Flat Glass ${ }^{24}$. Like in Irish Sugar ${ }^{25}$, the ECJ based its judgment on the arguments in the case France v. Commission ${ }^{26}$ and determined that

${ }^{21}$ ECJ judgment of 16.03.2000, Joined cases C-395/96 P and C-396/96 P Compagnie maritime belge transports $S A$ et al. v. Commission, ECLI:EU:C:2000:132.

22 ECJ judgment of 31.03.1998, Joined cases C-68/94 and C-30/95 French Republic and Société commerciale des potasses et de l'azote (SCPA) and Entreprise minière et chimique (EMC) v Commission, ECLI:EU:C:1998:148.

${ }^{23}$ CFI judgment of 25.03.1999, Case T-102/96 Gencor Ltd v. Commission, ECLI:EU:T:1999:65.

${ }^{24}$ CFI judgment of 10.03.1992, Joined cases T-68/89, T-77/89 and T-78/89 Società Italiana Vetro et al. v. Commission (Flat Glass), ECLI:EU:T:1992:38.

25 CFI judgment of 7.10.1999, Case T-228/97 Irish Sugar plc v. Commission, ECLI:EU:T:1999:246.

${ }^{26}$ Cases C-68/94 and C-30/95, supra note 21. 
collective dominance consists of a number of undertakings, which are together in this position, in particular due to factors contributing to links between them, in order to develop a joint policy on the market and actions far more independently of their competitors, their customers and ultimately their consumers ${ }^{27}$.

In Airtours $^{28}$, the CFI established that collective dominance exists where each member of the collectively dominant entity applies a conscious joint policy on the market on a long-term basis with the aim to sell even without entering into any agreement or acting jointly in the meaning provided for in Article 101 TFEU. This test was applied by the Commission and EU courts in a highly liberalised market, with established, transparent and competitive market conditions, and under conditions of information exchange, characterised also by the inability of sellers and consumers to influence the market.

All of the above mentioned cases reflect the behavioural approach of the Commission on defining collective dominance (see more: Petit, 2013, p. 325-332; Petit and Neyrinck, 2011; Monti, 2001, p. 131). European competition law doctrine, which is the basis for the approach of the Commission and EU courts, states that a structural analysis of the market is not sufficient to analyse collective dominance. The behavioural component in this case shall be the decisive factor (Joilet, 1970, p. 239-245). This opinion is defended by F. Mezzanotte in particular, who states that the EC shall prove the fact of coordinated (parallel) behaviour of the participants when justifying the finding of collective dominance. Otherwise, national competition authorities shall refrain from the collective dominance regime (Mezzanotte, 2010, p. 77-102).

In cases of collective dominance, it is not only the amount of quantitative indicators of the corresponding market shares that is calculated ${ }^{29}$. According to A. Jones and B. Sufrin, market share is not the only or the decisive factor in finding a dominant or collective dominant position (Jones and Sufrin, 2014, p. 305). A clear example is the judgment in France v. Commission where it was proven that the market share of two independent undertakings amounting to approximately $60 \%$ cannot conclusively mean the existence of a collective dominant position ${ }^{30}$.

27 Case T-228/97, supra note 24.

28 CFI judgment of 28.06.2004, Case T-342/99 Airtours plc v. Commission, ECLI:EU:T:2004:192. This was also established in: CFI judgment of 13 July 2006, Case T-464/04 Independent Music Publishers and Labels Association (Impala) v. Commission, ECLI:EU:T:2006:216.

${ }^{29}$ For example, Case T-228/97, supra note 24, paras 70-71.

30 Joined cases C-68/94 and C-30/95, supra note 21, para. 226. 
In Airtours $^{31}$, a three-component structural test was developed for determining collective dominance. First, each firm should know how other members are behaving (they could monitor the market to see if others were adopting possible policy changes); second, there should be evidences of tacit coordination, which is stable and non-transitory (no incentive to depart from the common policy); and third, foreseeable reactions of competitors (actual and potential), as well as consumers and customers would not jeopardise the results expected from the generally accepted policy.

However, the Impala ${ }^{32}$ judgment not only confirmed the existence of these three criteria for identifying collective dominance but also clearly stated the necessity to evidence them as well as evidence the characteristics of the market ${ }^{33}$. The definition of such criteria is the result of having considered the issue of collective dominance in previous cases. Hence, in particular in $T A C A^{34}$, the Commission analysed the relationship between enterprises as far as the coordination of their activities for the assessment of collective dominance. Later in the same case, the CFI clearly stated that in order to prove collective dominance there must be evidence of "factors of economic correlation between the enterprises" 35 .

Moreover, these criteria have been repeatedly used by the ECJ in various collective dominance judgments. For example, in Compagnie Maritime Belge Transports SA, Compagnie Maritime Belge $S A$ and Dafra-Lines A/S $v$ Commission, the ECJ confirmed that the term "one or more undertakings" means that the dominant position may be held by two or more undertakings legally independent of each other. In other words, from the economic point of view, they represent a collective entity or work together as one on the relevant market $^{36}$.

European practice also notes that such necessary element as coordination of actions of members of a collectively dominant entity may take

31 Case T-342/99, supra note 27.

32 Case T-464/04, supra note 27.

33 In an appeal from this case, ECJ expressed the conditions in slightly different terms. The substantive criteria were, however, in line with the views expressed by CFI; ECJ judgment of 10.07.2008, Case C-413/06 P Bertelsmann AG and Sony Corporation of America v. Independent Music Publishers and Labels Association (Impala), ECLI:EU:C:2008:392.

34 Commission Decision of 16.09.1998 relating to a proceeding pursuant to Articles 85 and 86 of the EC Treaty (Case No. IV/35.134 - Trans-Atlantic Conference Agreement), OJ L 095, 09.04.1999, p. 0001.

35 CFI judgment of 30.09.2003, Joined cases T-191/98, T-212/98 to T-214/98 Atlantic Container Line $A B$ and Others $v$ Commission, ECLI:EU:T:2003:245, para. 583.

36 Joined cases C-395/96 P and C-396/96 P, supra note 20, para. 32. 
various forms, in particular forms of direct coordination of a pricing policy ${ }^{37}$.

When it comes to the energy industry, both European doctrine (Scholz and Purps, 2011, p. 449) and judicial practice are currently in compliance with the criteria determined in the Amelo $^{38}$ case when proving collective dominance. The ECJ determined therein that in order to prove collective dominance, members of such group shall be connected in such a way as to adopt the same behaviour on the market.

The aforementioned confirms that the existence of collective dominance can be proven only on the basis of parallel cooperation. Moreover, the ECJ took this position in the case of Laurent Piau ${ }^{39}$. In the analysis of the doctrine and the national laws of EU Member States, it is also possible to assert that there is a synchronisation of the approaches between the EU judiciary and national competitive agencies ${ }^{40}$. As a result, the most common evidences of collective dominance are those of close parallel behaviour.

What can be seen in the legislation and enforcement practice in Ukraine in the sense of a comparative analysis? When applying Article 12 LPEC $^{41}$, the AMCU used a narrow, formalistic approach to existing domestic legislation and ignored the legislative requirements whereby market dominance should be determined using the criteria applied in such cases under EU law, in particular the criteria used in the law enforcement and judicial practice in the EU. Unlike the aforementioned examples of the use of the "collective dominance" concept by the Commission and EU courts, the AMCU's Report contains no justification when it comes to the composition of the "collective dominance". The same can be said about the lack of evidence of the existence of any joint (coordinated) policy, in particular concerning prices, as well as the

37 DG Competition discussion paper of 2005 on the application of Article 82 of the Treaty to exclusionary abuses, supra note 9, para. 47.

38 ECJ judgment of 27.04.1994, Case C-393/92 Municipality of Almelo and others $v$ NV Energiebedrijf Ijsselmij, ECLI:EU:C:1994:171.

39 CFI judgment of 26.01.2005, Case T 193/02, Laurent Piau v. Commission, ECLI:EU:T:2005:22.

${ }^{40}$ For example: Brannigan v. OFT (2007) CAT 23 (106); OFT/CC, Market Investigation References (Ref: OFT511) (2002). The Guidance has since been adopted by the CMA and is available on the CMA website; Interbrew SA/Bass plc Cm 5014 (2001) and Lloyds TSB Group plc/Abbey National plc Cm 5208 (2001); the Italian Antitrust Authority's approach in the AEM/ ASM Brescia Case (2007).

41 Article 12 LPEC provides that the monopoly (dominant) position is considered to be the entity whose market share exceeds 35 percent of the goods if it proves experiencing considerable competition. And also it provides that the monopoly (dominance) may also be recognized position of an entity if the market share of goods is 35 percent or less, but it does not undergo considerable competition, particularly because of the relatively small size of the market shares that belong to competitors. 
ability and motivation of the members to implement such policy (conditions of market transparency and information awareness of its participants, possibility to coordinate their actions and punish those that try to avoid such coordination etc.). Accordingly, the conclusions of the AMCU are in conflict with Ukrainian law with regard to its international obligations to apply acquis. They are also incorrect as far as the existence of "collective dominance" is concerned in the electricity market of Ukraine as they contradict the actual circumstances of this market.

It is essential to note that the behavioural aspect of collective dominance also appears from the analysis of the provisions of Articles 1 and 12 LPEC and the provisions of AMCU's special Act on methodology concerning the determination of the monopoly (dominating) position of undertakings ${ }^{42}$. In particular, Part 5 of Article 12 LPEC is a special qualifying provision that stipulates such situation on the market when, in contrast to individual dominance of a given undertaking, the ability to determine (or fundamentally influence) the conditions of market trade in goods belongs to an undertaking not independently but jointly with other undertakings - in other words, to a group of undertakings as a collective entity. The provisions of Article 12 also indicate that the aggregate share of undertakings formed jointly (but not cumulative, i.e. the share obtained arithmetically), is a structural indicator that serves as a base for the determination of dominance. It means that the market (monopoly) power belongs precisely to the undertakings taken together so called "collective dominant entity" - and this power exists because of their common (joint) behaviour. The "object" of the analysis in this case is a "collectively dominant entity", and its market power as a collective entity that acts as opposed to other participants of the market. "Collectiveness" is expressed by the aggregated market power of all members of the collective entity demonstrated in a specific coordination and, similarity, parallelism of competitive behaviour among the members of the group. Precisely due to such combination, a collective entity has the possibility to obtain supra-competitive advantages, determine conditions of trade, block or limit competition, in particular increase prices, all of which would be impossible individually for the separate members of the collectively dominant entity.

Accordingly, in this case any abuse of such monopolistic position shall be also considered with respect of all members of the "collectively dominant entity" taken together because in this case any dominance and market (monopoly) power are impossible beyond the boundaries of such group. Accordingly, any negative influence on competition in the form of any

42 Order of the Anti-Monopoly Committee of Ukraine No. 49-p of 05.03.2002 on the Approval of the Methods of Defining the Monopoly (Dominant) Position of Undertakings in the Market, The Official Bulletin of Ukraine 2002, No. 14, p. 396. 
abuse of the monopolistic position (dominance) can be a consequence of the joint behaviour of precisely the united "collective entity", but cannot be a consequence of the activity/inactivity of its individual members. Since the market power and the monopolistic position (dominance) belong in this case precisely to the "collective entity", it is possible to use the advantages exclusively in favour of all members of such entity, but not unilaterally in favour of any of its separate members.

So the necessity to prove the links and coordination of the competitive behaviour among the members of a "collectively dominant entity" in order to apply the qualification criterion specified in paras 4-5 of Article 12 LPEC is a compulsory element of the structural analysis of "collective dominance". Its absence proves the absence of a legal basis for the qualification of the undertakings" position as a "collective dominance" - a fact not taken into account by the AMCU in its investigation. In its Report, the AMCU did not present proofs or evidences that the three electricity generating companies which the authority saw as holding a collective dominance had been, in fact, linked by agreements or ownership interests. As a result, no "structural links" were identified that could underpin a finding of collective dominance.

Moreover, in light of the AMCU's market inquiry findings of 24 December $2015^{43}$, it would seem that the AMCU had not conducted a comprehensive market analysis or found the existence of tacit collusion before ultimately concluding that the three generators concerned hold a collective dominant position on the Ukrainian electricity generation market. It did so despite the fact that these three companies have significantly different cost structures and fluctuating market shares. In fact, the three generators have inherently different cost structure because of the composition of their generation technologies and resources.

These facts strongly suggest that the generators concerned would have no incentive to engage in tacit collusion ${ }^{44}$ and there is no indication in the AMCU's market inquiry findings that they have actually done so. Indeed, there is no discussion of the generators acting as a collective entity independently of competitors, customers and consumers. It would seem that dominance is

43 The text of AMCU's presentation of the Report (text available only in Ukrainian) can be accessed at http://www.amc.gov.ua/amku/doccatalog/document?id=119661\&schema=main (26.09.2016).

${ }^{44}$ In Case COMP/M.5224 - EDF/British Energy (2008), para. 29, the Commission made clear that the merger raised concerns because it would bring together British Energy's mostly baseload production with EdF's flexible production, raising the potential concern that the combined entity would, as a result of the merger, withdraw production to increase prices that it gets on the plants that it is producing. It is clear from the Commission's analysis, the incentives are fundamentally different when baseload and flexible capacity belongs to distinct undertakings as in the Ukrainian generation sector. 
found on the basis of their combined market shares alone, without regard to the actual functioning of the markets or an analysis whether the undertakings concerned have actually engaged in a joint market policy. As explained further below, this approach falls far short of the requirements of EU competition law.

\section{Conclusions}

According to European experts (Chauve, Godfried, Kovács, Langus, Nagy and Siebert, 2009, p. 51-54), the electricity sector as a whole is characterised by its uniformity (homogeneity) with a low elasticity of demand, which deprives customers of usual instruments to regulate prices and supplies. When it comes to the supply side of the industry, the latter is also characterised by significant discrepancies between expenses for the implementation of different manufacturing technologies, which are not reflected in the price formation of the supplier.

In European practice, there are single cases connected with competition rules in the electricity market ${ }^{45}$, most of which relate to concentrations ${ }^{46}$ and state aid procedures ${ }^{47}$. However, some cases on the abuse of dominance can be identified also. In this context, it is essential to refer to the analysis of the E.ON case $(2008)^{48}$.

Significant governmental influence on the pricing in the Wholesale Electricity Market and administrative regulation of production volumes are in fact two of the most important factors influencing the competitive functioning of the electricity market in Ukraine. The 2008 decision of the European Commission in E.ON was based on the particular features of the German

45 In the whole history of the EU, the Commission examined only 17 cases connected with different violations of competition rules in the field of power engineering: http://ec.europa.eu/ competition/elojade/isef/index.cfm?fuseaction $=$ dsp_result \&nace_code $=96100,96060,96110,96$ $120,96130,96140 \&$ policy_area_id=1 (26.09.2016).

${ }^{46}$ For example, EDF/London Electricity, OJ C 387 of 12.12.1998; Electrabel/Epon, OJ C 13 of 18.01.2000; E.ON Energie/Energie Oberösterreich/JCE +JME, OJ C 16 of 18.01.2001; Macquarie/ Wren House/E.ON Spain, OJ C 51 of 13.02.2015.

47 Modification of Electricity Production Grant (DK), OJ C 292, 04.09.2015; Förderschwerpunkt Elektromobilität des BMVBS, OJ C 296, 07.10.2011; Green Deal for Electric Vehicle Charging Infrastructure (http://ec.europa.eu/competition/elojade/isef/case_ details.cfm?proc_code =3_SA_38769, 26.09.2016).

48 Commission Decision of 26.11.2008 relating to a proceeding under Article 82 of the EC Treaty and Article 54 of the EEA Agreement (Cases COMP/39.388 - German Electricity Wholesale Market and COMP/39.389 - German Electricity Balancing Market), http://ec.europa. eu/competition/antitrust/cases/dec_docs/39388/39388_2796_3.pdf (26.09.2016). 
market (Section 4.2. of the Decision), namely its structural and behavioural parameters (ability to adopt a common policy concerning prices).

According to European practice, it is possible to conclude that the AMCU Report and its conclusions on the issue of collective dominance do not contain an analysis of the conditions that should have been taken into account when deciding on the existence of collective dominance. These include question such as: (i) under which conditions can members of a collectively dominant entity obtain information on the behaviour of other market participants; (ii) under which conditions can members of a collectively dominant entity influence an undertaking which, in the case of an agreement between them - can restrict competition, and in case of coordinated activities - avoid the common policy in this market; (iii) under which conditions shall the expected reaction of competitors (existing and potential) not significantly influence the expected result of the agreed actions (jointly implemented by members of the collectively dominant entity in the targeted market); (iv) under which conditions are there economic, legal and structural links present between the members of the collectively dominant entity that provide an opportunity to implement the joint policy, in particular on prices; (v) under which conditions do members of the collectively dominant entity hold market power (that is, can they act independently from buyers, customers and competitors). It is obvious that a sufficient link or connection between them should have been the core concept of the analysis of this case.

Due to the fact that the national electricity market of Ukraine is rigorously shaped by legislation, any assessment of its separate elements should have been carried out with consideration of all its dependences and an analysis of the potential market power of its participants should have first of all considered their relations with public regulatory authorities. A statement that declares the existence of collective dominance held by the three electricity generators, without proving the existence of a coordinated policy and parallelism between them, is thus superficial. This realisation is especially valid taking into account the fact that they act in the strictly legislated field of electricity demand and supply pricing, the policy on which is formed unilaterally by NEURC.

Thus it can be stressed that competition is absent on the Ukrainian electricity market. The model market, where the cost of electricity does not affect the volume of purchases, where buying/selling takes place only through GP "Energy", and 70\% of all electricity is sold at pre-set NEURC tariffs, require a fundamental reform that is provided by the third EU energy package $^{49}$.

49 It was officially confirmed by an AMCU representative, as can be seen from the slides presented (text available only in Ukrainian) at http://www.slideshare.net/EnergyReformUA/ ss-63563443 (26.09.2016). 
So it can be concluded that the "single buyer" market model, combined with governmental regulations represented by SE Energorynok and NEURC, illustrates the actual absence of market power of the electricity producers (generation companies) and, as a result, the absence of a level of independence required for the determination of dominance according to EU law. So the wholesale electricity market can be characterised by a state of institutional monopoly, depriving the participants of their market power as a result of governmental control. It is so also because the conditions of market trade are regulated and determined by governmental authorities.

As a result, the AMCU's approach to the regulation of the electricity market in Ukraine confirms the need to reform the system of governmental regulation in the domestic wholesale electricity market and in the market of services for electricity transmission. It also highlights the necessity to change the system for tariff and price-policy formation on the part of NEURC and the Ministry of Energy and Coal-Mining Industry of Ukraine in order to develop competition in the national electricity market. The need to follow the approach and criteria of EU competition law is also apparent with regard to the determination of market dominance. The latter is stipulated by international law duties biding Ukraine under Articles 18 and 94 of the Treaty establishing the Energy Community and Article 255 of the EU-Ukraine Association Agreement.

\section{Literature}

Chauve, P., Godfried, M., Kovács, K., Langus, G., Nagy, K. and Siebert S. (2009). The E.ON electricity cases: an antitrust decision with structural remedies. Competition Policy Newsletter, 1, 51-54.

Joilet, R. (1970). Monopolisation and abuse of dominant position - a comparative study of the American and European approaches to the control of economic power. The Hague: Martinus Nijhoff.

Jones, A. and Sufrin, B. (2014). EU Competition Law. Text, cases and materials. Oxford: Oxford University Press.

Mezzanotte, F. (2010). Using Abuse of Collective Dominance in Article 102 TFEU to Fight Tacit Collusion: The Problem of Proof and Inferential Error. World Competition, 33(1), 77-102.

Monti, G. (2001). The Scope of Collective Dominance Under Article 82. Common Market Law Review, 38, 131-157.

Monti, G. (2006). The Concept of Dominance in Article 82. European Competition Journal, $2(31), 31-52$.

Ortiz Blanco, L. (2012). Market Power in EU Antitrust Law. Oxford: Hart Publishing. 
Petit, N. (2013). Collective dominance as effective tacit collusion. In: I. Lianos, D. Geradin (eds.), Handbook on European Competition Law, substantive aspects. Cheltenham: Edward Elgar, 325-332.

Petit, N. and Neyrinck, N. (2011). Collective Dominance: an overview of national case law. e-Competitions, 39129, October 2011.

Rosen, R. and Williams, E. (1999). A Better Approach to Market Power Analysis. Boston: Tellus Institute.

Scholz, U. and Purps, S. (2011). The application of EC Competition law in the Energy Sector. World Competition, 34, 62-77.

Smyrnova, K. (2014). Enforcement of Competition Rules in the Association Agreement between EU \& Ukraine. Yearbook of Antitrust \& Regulatory Studies, 7(10), 263-278.

Smyrnova, K.V. (2015). The implementation of the competition provisions in the Association Agreement between Ukraine and the European Union. Law of Ukraine, $8,75-82$.

Vickers, J. (2006). Market Power in Competition Cases. Competition Law Journal, 2(3), 3-14. 